\title{
Selective Regulation of trkC Expression by NT3 in the Developing Peripheral Nervous System
}

\author{
Sean Wyatt, Gayle Middleton, Epaminondas Doxakis, and Alun M. Davies \\ School of Biological and Medical Sciences, University of St. Andrews, St. Andrews, Fife KY16 9AJ, Scotland
}

\begin{abstract}
We have studied the influence of neurotrophin-3 (NT3) on the expression of its receptor tyrosine kinase, trkC, in embryonic mice. The expression of trkC transcripts encoding full-length and kinase-deficient receptors was almost entirely restricted to neurons in the trigeminal ganglion and increased markedly throughout development. In NT3 ${ }^{+/-}$embryos, the level of trkC mRNA in the trigeminal ganglion was much lower than that in wild-type embryos, although there was no significant reduction in the total number of neurons in the ganglion. This demonstrates that endogenous NT3 regulates trkC expression in trigeminal neurons independently of changes in population size. In $N T 3^{-1-}$ embryos, the number of neurons in the trigeminal ganglion was much lower than in wild-type embryos, and there was a further reduction in the mean neuronal level of trkC $m R N A$. Direct regulation of trkC mRNA expression in cultured trigeminal neurons was also observed, although the finding that
\end{abstract}

The neurotrophins, nerve growth factor (NGF), brain-derived neurotrophic factor (BDNF), neurotrophin-3 (NT3), and neurotrophin-4 (NT4), are secreted proteins that promote the survival of neurons in the developing nervous system by signaling via members of the trk family of receptor tyrosine kinases (TKs) (Bothwell, 1995). Expression studies in cell lines have shown that trkA is a receptor for NGF (Hempstead et al., 1991; Kaplan et al., 1991; Klein et al., 1991a), trkB is a receptor for BDNF and NT4 (Berkemeier et al., 1991; Glass et al., 1991; Klein et al., 1991b; Soppet et al., 1991; Squinto et al., 1991; Ip et al., 1992), and trkC is a receptor for NT3 (Lamballe et al., 1991). NT3 is also able to bind and signal less efficiently via trkA and trkB in cell lines (Lamballe et al., 1991; Soppet et al., 1991; Squinto et al., 1991; Ip et al., 1993) and developing neurons (Davies et al., 1995a), which explains why the phenotype of $N T 3^{-1-}$ mice is more severe than that of $t r k C^{-1-}$ mice (Ernfors et al., 1994; Klein et al., 1994; Schimmang et al., 1995; Farinas et al., 1996).

Trks are transmembrane glycoproteins that possess an intracellular region that contains the catalytic TK domain and an extracellular, ligand-binding region with a complex subdomain organization (Schneider and Schweiger, 1991). trkB and trkC variants lacking the TK domain (Klein et al., 1990a,b; Lamballe et al.,

\footnotetext{
Received Feb. 11, 1999; revised May 6, 1999; accepted May 7, 1999.

This work was supported by a grant from the Wellcome Trust. We thank Patrik Ernfors of the Karolinska Institute for the NT3 mutant mice, Gene Burton of Genentech Inc. for the purified recombinant NT3, and Debbie Hughes for assistance with genotyping.

Correspondence should be addressed to Alun Davies, School of Biological and Medical Sciences, Bute Medical Buildings, University of St. Andrews, St. Andrews, Fife KY16 9AJ, Scotland.

Copyright (C) 1999 Society for Neuroscience 0270-6474/99/196559-12\$05.00/0
}

trkC mRNA levels were sustained better in explant cultures than in dissociated cultures irrespective of the presence of NT3 suggests that trkC mRNA expression is regulated by additional factors within the ganglion. In contrast to trigeminal neurons, the level of trkC mRNA was sustained at normal levels in neurons of the sympathetic chain of $N T 3^{-1-}$ embryos and was not increased by NT3 in sympathetic neuron cultures. TrkC mRNA expression in developing cutaneous tissues was also unaffected by the NT3 null mutation. In summary, our findings provide the first clear evidence that the expression of a trk receptor, tyrosine kinase, is regulated by physiological levels of its ligand in vivo and show that regulation by NT3 is cell type-specific.

Key words: Trk receptor; neurotrophin; sensory neuron; sympathetic neuron; NT3 knock-out; mouse

1993; Tsoulfas et al., 1993) are widely expressed by non-neuronal cells (Klein et al., 1990b; Merlio et al., 1992; Beck et al., 1993; Frisen et al., 1993; Funakoshi et al., 1993; Rudge et al., 1994; Biffo et al., 1995) and by some neurons (Armanini et al., 1995; Ninkina et al., 1996). These noncatalytic receptors are thought to play a role in limiting the diffusion of their neurotrophin ligands (Biffo et al., 1995), and $\mathrm{TK}^{-}$trkB may act as a negative modulator of BDNF signaling at certain stages of sensory neuron development (Ninkina et al., 1996).

In addition to the trks, all neurotrophins bind to the common neurotrophin receptor $\mathrm{p} 75$, a transmembrane glycoprotein with diverse functions. In neurons coexpressing trk receptors, it selectively enhances responsiveness to NGF (Davies et al., 1993; Horton et al., 1997; Ryden et al., 1997), decreases responsiveness to NT3 (Benedetti et al., 1993; Clary and Reichardt, 1994; Lee et al., 1994), and may play a role in ligand discrimination by trkB (Ryden et al., 1995). In the absence of trk signaling, p75 mediates a cytotoxic response to NGF and BDNF in some cells (CasacciaBonnefil et al., 1996; Frade et al., 1996; Van der Zee et al., 1996; Yeo et al., 1997; Davey and Davies, 1998).

Different populations of neurons have distinctive requirements for particular neurotrophins at certain stages of their development (Davies, 1994; Snider, 1994; Lewin and Barde, 1996), and some neurons switch their neurotrophin requirements from one neurotrophin to another during development (Davies, 1997). There is considerable evidence that the onset and changes in responsiveness to particular neurotrophins is correlated with marked increases in the expression of their corresponding trk receptors (Wyatt and Davies, 1993, 1995; Ninkina et al., 1996; Robinson et al., 1996). Thus, elucidating what regulates neurotrophin receptor expression is a key element in understanding 
how trophic interactions are coordinated in the developing nervous system.

Several in vitro and in vivo studies have shown that exogenous neurotrophins are able to increase the expression of their corresponding receptors. For example, the level of p75 mRNA is increased by NGF in sympathetic (Miller et al., 1991, 1994; Verdi and Anderson, 1994; Wyatt and Davies, 1995), sensory (Lindsay et al., 1990; Verge et al., 1992; Wyatt and Davies, 1993), and basal forebrain cholinergic neurons (Cavicchioli et al., 1989; Higgins et al., 1989; Fusco et al., 1991; Kojima et al., 1992) and by BDNF in sensory neurons (Wyatt and Davies, 1993). Exogenous NGF increases the level of trkA mRNA in forebrain cholinergic neurons in vivo (Holtzman et al., 1992; Venero et al., 1994) and in vitro (Kojima et al., 1994) and, in combination with estrogen, increases the level of trkA mRNA in PC12 cells (Sohrabji et al., 1994). Likewise, BDNF increases the expression of trkB transcripts in cultured sensory neurons (Ninkina et al., 1996). Although these studies of the effects of supraphysiological levels of neurotrophins demonstrate that neurotrophins are capable of regulating expression of their receptors, the relevance of these kinds of studies for understanding how neurotrophin receptor expression is normally regulated during development has been questioned by studies of NGF knock-out mice. The finding that the timing and level of expression of both p75 and trkA mRNAs is entirely normal in the sensory neurons of $\mathrm{NGF}^{-1-}$ mouse embryos (Davies et al., 1995b) suggests that NGF plays no role in the regulation of NGF receptor expression during development. Likewise, the induction of trkB expression in developing sensory neurons is entirely normal in $B D N F^{-1-}$ embryos (K. Huber, S. Wyatt, and A. M. Davies, unpublished data). These latter surprising observations emphasize the need to study the effects of endogenous neurotrophins to ascertain their physiological significance in controlling receptor expression.

In the present study we have used a similar genetic approach to study the role of endogenous NT3 in regulating the expression of $\mathrm{TK}^{+}$and $\mathrm{TK}^{-}$trkC transcripts in two populations of neurons of the embryonic peripheral nervous system and $\mathrm{TK}^{-}$trkC mRNA in developing cutaneous tissues. The sensory neurons of the trigeminal ganglion and the sympathetic neurons of the superior cervical sympathetic ganglion (SCG) initially survive independently of neurotrophins during the earliest stages of their development (Davies and Lumsden, 1984; Coughlin and Collins, 1985; Ernsberger et al., 1989). Most neurons born during the early stages of neurogenesis in the trigeminal ganglion become dependent on either NT3 or BDNF for survival, and many of these neurons together with neurons born during the later stages of neurogenesis subsequently become dependent on NGF for survival (Buchman and Davies, 1993; Paul and Davies, 1995; Piñón et al., 1996; Wilkinson et al., 1996; Huang et al., 1999) (Y. Enokido, S. Wyatt, and A. M. Davies, unpublished data). SCG neurons first become dependent on NGF for survival before acquiring an additional requirement for NT3 much later in development (Wyatt et al., 1997). Here we report that the expression of both $\mathrm{TK}^{+}$and $\mathrm{TK}^{-}$trkC mRNA levels is reduced in trigeminal neurons but not in SCG neurons or cutaneous tissues in mouse embryos with a null mutation in the NT3 gene. This shows that endogenous NT3 selectively regulates the expression of trkC in trigeminal neurons during development and is the first physiologically relevant demonstration of the regulation of neurotrophin receptor expression by its ligand.

\section{MATERIALS AND METHODS}

Experimental animals and tissues. Embryos were obtained from overnight matings of wild-type CD1 mice or $N T 3^{+/-}$mice (a gift from Patrik Ernfors, Karolinska Institute, Stockholm, Sweden) (Ernfors et al., 1994). Pregnant females were killed by cervical dislocation at the required stage of gestation, and the precise stage of development of the embryos was determined by the criteria of Theiler (1972). For embryos resulting from crossing $N T 3^{+/-}$mice, DNA was extracted from undissected tissues to determine the genotypes by PCR using primers specific for the wild-type and mutated NT3 genes.

Tungsten needles were used to dissect the trigeminal ganglia, SCG, and the whiskerpads from staged embryos. Tissues were either frozen and stored at $-70^{\circ} \mathrm{C}$ for RNA extraction or processed for explant or dissociated culture.

Neuron cultures. For dissociated cultures, trigeminal or sympathetic ganglia were trypsinized, dissociated, and plated at low density in polyornithine-laminin-coated 35 -mm-diameter plastic tissue culture dishes (500-2000 neurons per dish) in $2 \mathrm{ml}$ of defined medium, as described previously (Davies et al., 1993). The cultures were incubated at $37^{\circ} \mathrm{C}$ in a $5 \% \mathrm{CO}_{2}$ incubator for up to $48 \mathrm{hr}$. To ascertain the proportion of neurons surviving in these cultures, the number of attached neurons within a $12 \times 12 \mathrm{~mm}$ square in the center of each dish was counted $6 \mathrm{hr}$ after plating. The number of surviving neurons in the same area was counted at intervals and expressed as a percentage of the initial number of neurons counted. For explant cultures, single ganglia were cultured in separate $16 \mathrm{~mm}$ wells containing $0.5 \mathrm{ml}$ of serum-free medium.

Quantification of $m R N A$ levels. A quantitative, competitive RT-PCR technique (Wyatt and Davies, 1993) was used to measure the levels of trkC and glyceraldehyde phosphate dehydrogenase (GAPDH) mRNAs in tissues dissected from wild-type and NT3 ${ }^{-1-}$ embryos and in cultures established from these embryos. The RT and PCR reactions were calibrated by the inclusion of known amounts of cRNA competitor templates for each of the mRNAs in the RT reaction. Alternative splicing generates transcripts that encode trkC variants that either possess or lack the catalytic tyrosine kinase domain (Lamballe et al., 1993; Tsoulfas et al., 1993; Valenzuela et al., 1993). The levels of mRNAs encoding catalytic $\left(\mathrm{TK}^{+}\right)$and noncatalytic $\left(\mathrm{TK}^{-}\right)$trkC variants were measured using primers specific for mouse $\mathrm{TK}^{+}$transcripts and primers in the extracellular domain that amplify all mouse trkC transcripts. It is not possible to design a single RT-PCR assay to measure all of the mRNAs that encode $\mathrm{TK}^{-}$trkC variants directly because there is no exonic sequence common to and specific for all $\mathrm{TK}^{-}$trkC mRNAs (Valenzuela et al., 1993). The level of $\mathrm{TK}^{-}$mRNAs was therefore calculated by subtracting $\mathrm{TK}^{+}$ mRNA from total trkC mRNA. The details of the primers, control templates, reaction conditions, and quantification are provided elsewhere (Wyatt and Davies, 1995, 1997).

\section{RESULTS}

\section{Time course of trkC mRNA expression in developing trigeminal neurons}

The levels of both $\mathrm{TK}^{+}$and $\mathrm{TK}^{-}$trkC mRNAs were relatively low during the early stages of trigeminal ganglion development at embryonic day 10 (E10) and increased markedly with embryonic age (Fig. 1). The levels of these mRNAs increased $>25$-fold between E10 and the end of embryonic development at E18. Throughout this period, the level of $\mathrm{TK}^{-}$trkC mRNA was between 15- and 25-fold higher than that of $\mathrm{TK}^{+} \operatorname{trkC}$ mRNA.

To determine whether $\mathrm{TK}^{+}$and $\mathrm{TK}^{-}$trkC transcripts are expressed by either neurons or non-neuronal cells in the developing trigeminal ganglion, differential sedimentation was used to separate neurons from other cell types (Davies, 1986). This procedure was performed at E16 and postnatal day 1 (P1) when the size difference between neurons and non-neuronal cells in the ganglion was large enough to obtain neuronal and non-neuronal cell preparations of $>95 \%$ purity. At both ages, the levels of $\mathrm{TK}^{+}$ trkC mRNA were substantially higher in the neuronal fraction than in the non-neuronal fraction (between 40- and 44-fold higher), suggesting that full-length trkC is expressed mainly if not exclusively in neurons (Fig. 2). The levels of $\mathrm{TK}^{-}$trkC mRNA were also much higher in the neuronal fraction than in the 


\section{trkC TK+}

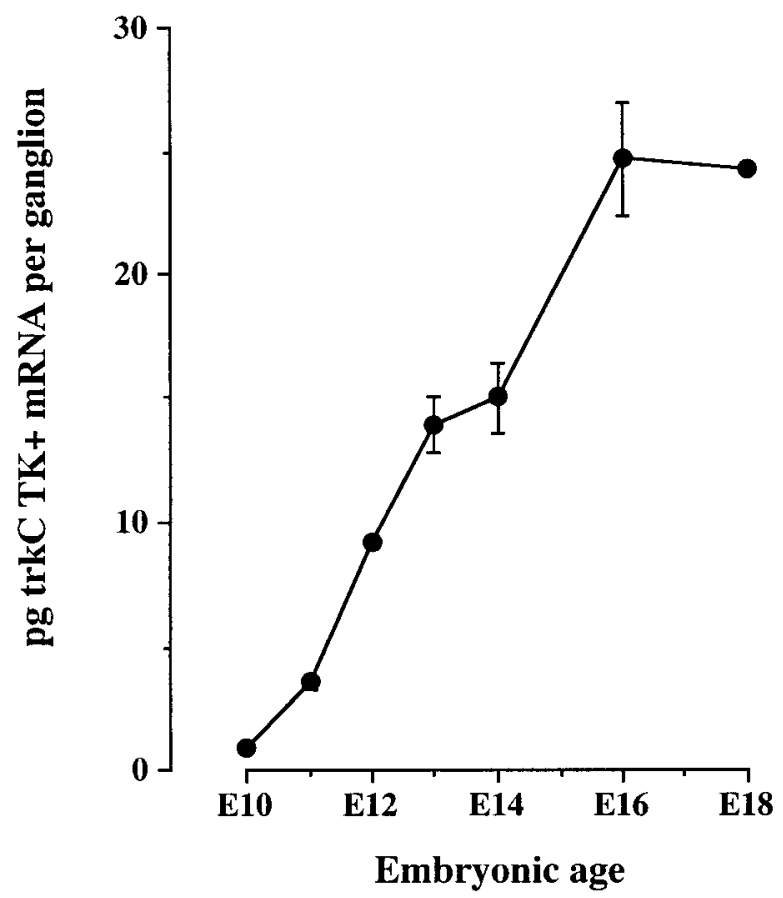

\section{trkC TK-}

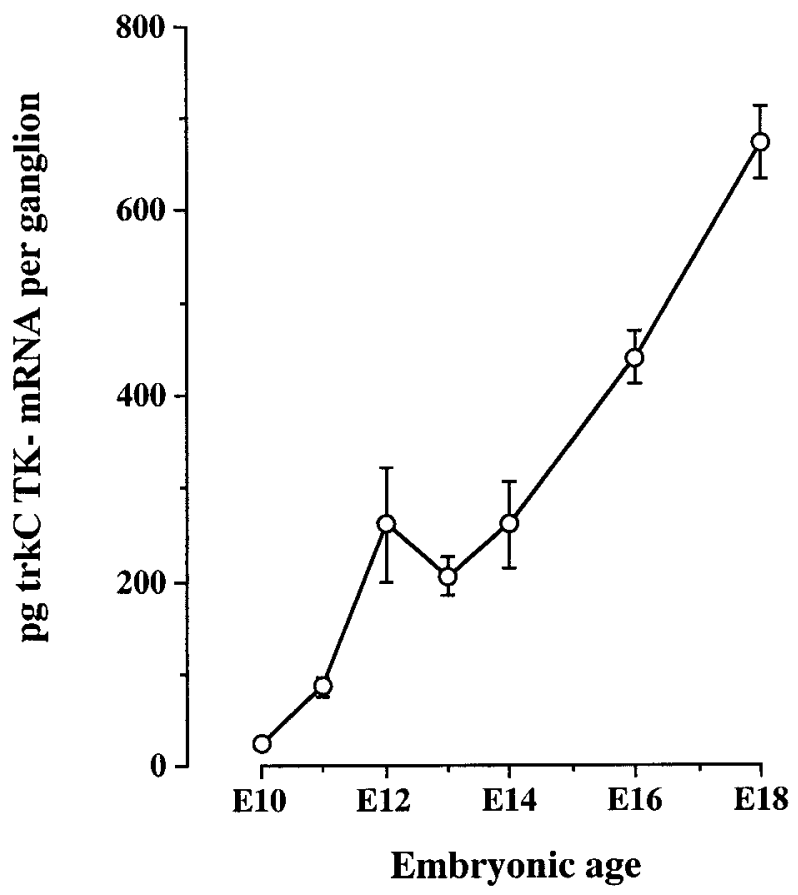

Figure 1. Levels of $\mathrm{TK}^{+}$and $\mathrm{TK}^{-}$trkC transcripts in the trigeminal ganglia of E10-E18 mouse embryos. The mean and SEM of between three and five separate measurements are shown for each stage.

\section{trkC TK+}

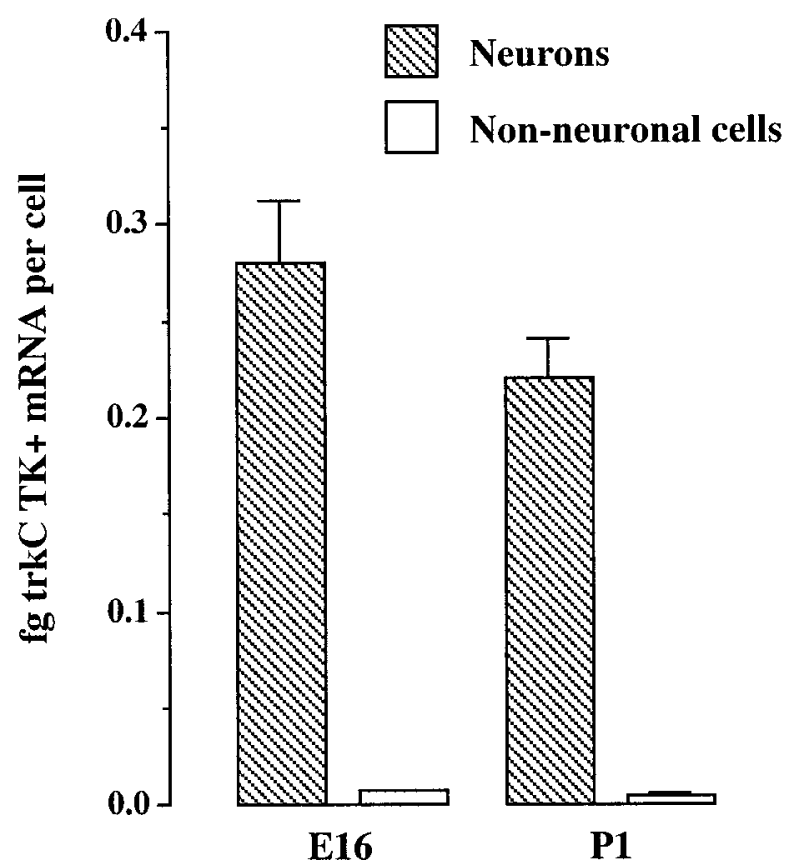

trkC TK-

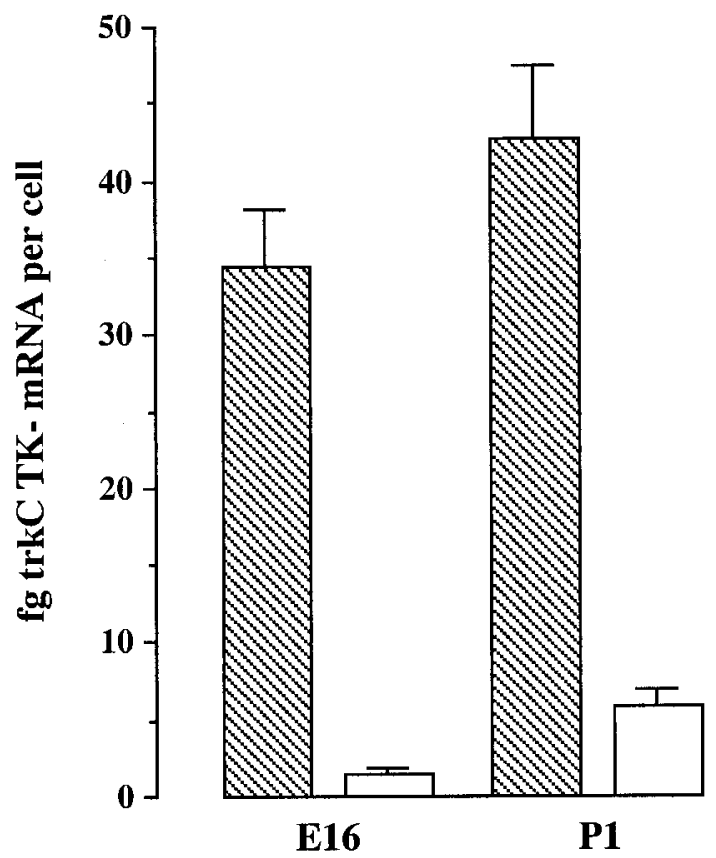

Figure 2. Levels of $\mathrm{TK}^{+}$and $\mathrm{TK}^{-}$trkC transcripts in neurons and non-neuronal cells purified from E16 and P1 trigeminal ganglia. The mean and SEM of three separate neuronal and non-neuronal cell samples are shown for each age. 


\section{GAPDH mRNA}

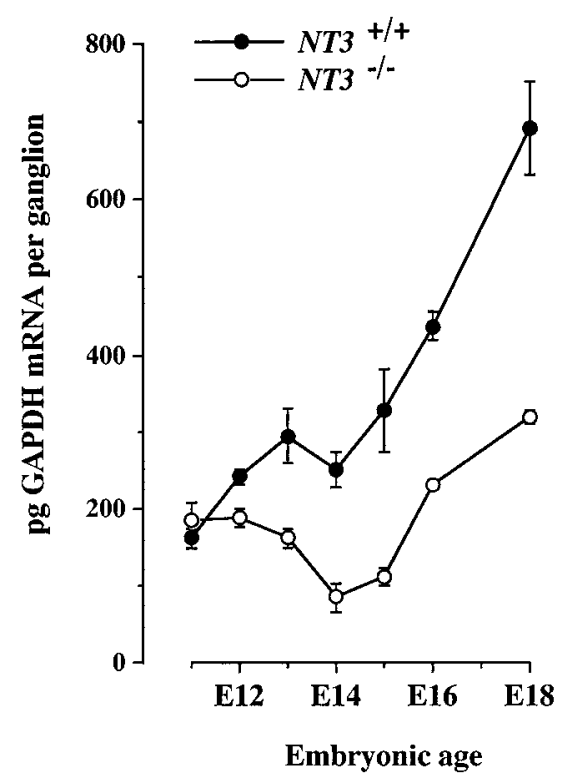

trkC TK+ mRNA

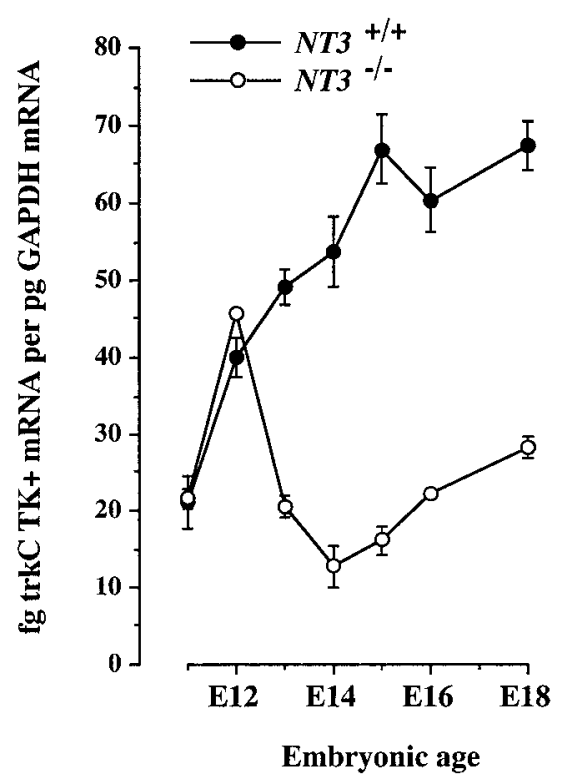

\section{trkC TK- mRNA}

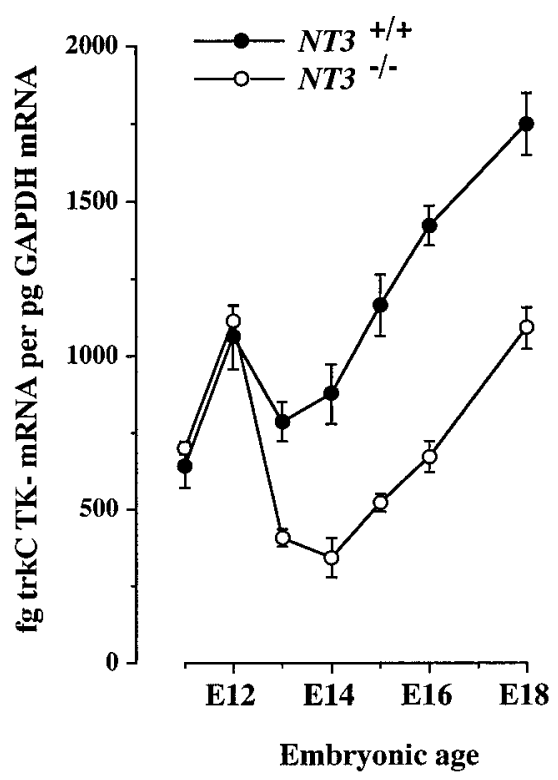

Figure 3. Levels of GAPDH mRNA and levels of $\mathrm{TK}^{+}$and $\mathrm{TK}^{-}$trkC transcripts relative to GAPDH mRNA in the trigeminal ganglia of E11-E18 $N T 3^{+/+}$and $N T 3^{-/-}$mouse embryos. The mean and SEM of measurements from ganglia of three to seven animals of each genotype at each age are shown.

non-neuronal fraction (between 7- and 14-fold higher), suggesting that truncated trkC is also expressed mainly in neurons (Fig. 2). However, because the ratio of $\mathrm{TK}^{-}$trkC mRNA in non-neuronal cells versus neurons is higher than the ratio of $\mathrm{TK}^{+}$trkC mRNA in non-neuronal cells versus neurons, it is possible that unlike $\mathrm{TK}^{+}$trkC mRNA there may be a relatively low level of $\mathrm{TK}^{-}$trkC mRNA expressed in non-neuronal cells.

\section{Regulation of trkC expression in trigeminal neurons by endogenous NT3}

To investigate if endogenous NT3 plays a role in regulating the levels of $\mathrm{TK}^{+}$and $\mathrm{TK}^{-}$trkC mRNAs in developing trigeminal ganglia in vivo, the levels of these mRNAs were measured in the trigeminal ganglia of wild-type and $N T 3^{-/-}$mice throughout development. Because large numbers of cells are lost during the early stages of sensory ganglion development in $N T 3^{-1-}$ embryos, we used competitive RT-PCR to quantify the levels of mRNA encoding the ubiquitous, constitutively expressed "housekeeping" protein GAPDH.

There was no reduction in the level of GAPDH mRNA in the trigeminal ganglia of $N T 3^{-/-}$embryos compared with wild-type embryos at E11 (Fig. 3), suggesting that there are similar numbers of cells in the trigeminal ganglia of wild-type and NT3-deficient embryos at developmental stages up to E11. However, the level of GAPDH mRNA was significantly lower in the trigeminal ganglia of $N T 3^{-1-}$ embryos at E12 ( $p<0.05 ; t$ test $)$, and the disparity in the GAPDH mRNA levels between $N T 3^{-1-}$ and wild-type embryos increased with embryonic age (Fig. 3). This suggests that there are fewer cells in the trigeminal ganglia of $N T 3^{-1-}$ embryos at E12 and older ages compared with wild-type embryos. The gradual decrease in the level of GAPDH mRNA in NT3-1embryos between E12 and E14 is consistent with the loss of cells in the ganglion over this period of development. Very similar developmental changes were observed in the levels of mRNAs encoding neuron-specific proteins like the Brn-3a transcription and trkA in the trigeminal ganglia of $N T 3^{-1-}$ and wild-type embryos (data not shown).

There were no significant differences in the levels of $\mathrm{TK}^{+}$trkC mRNA relative to GAPDH mRNA in the trigeminal ganglia of wild-type and $N T 3^{-1-}$ embryos at E11 and E12 (Fig. 3). This suggests that the mean level of $\mathrm{TK}^{+}$trkC mRNA in cells of the trigeminal ganglion is similar in wild-type and NT3-deficient embryos at developmental stages up to E12. However, by E13 there was a marked decrease in the level of $\mathrm{TK}^{+}$trkC mRNA relative to GAPDH mRNA in the trigeminal ganglia of $N T 3^{-/-}$ embryos, and this deficiency in $\mathrm{TK}^{+}$trkC mRNA in the cells of the trigeminal ganglia of NT3-deficient embryos was maintained throughout the subsequent stages of embryonic development. Similar trends in the developmental profile of $\mathrm{TK}^{-}$trkC mRNA expression relative to GAPDH mRNA were observed in the trigeminal ganglia of wild-type and $N T 3^{-1-}$ embryos; no significant differences at E11 and E12 but a decrease in NT3-deficient embryos at E13 and later ages, although the relative decrease in the level of $\mathrm{TK}^{-}$trkC mRNA was not as great as that of $\mathrm{TK}^{+}$ trkC mRNA. These results suggest that in the absence of endogenous NT3, the mean levels of $\mathrm{TK}^{+}$and $\mathrm{TK}^{-}$trkC mRNAs in cells of the trigeminal ganglion decrease markedly after E12. Very similar trends were observed if the trkC data were expressed relative to Brn-3a mRNA or trkA mRNA rather than GAPDH mRNA (data not shown).

The decreased level of trkC mRNA relative to GAPDH mRNA in the trigeminal ganglia of $N T 3^{-/-}$embryos after E12 could reflect a reduction in the mean level of trkC transcripts in trkC-expressing cells, the selective loss of these cells, or a combination of the two. The observed reduction in the number of neurons in the dorsal root and trigeminal ganglia of NT3 ${ }^{-1-}$ embryos (ElShamy and Ernfors, 1996a,b; Farinas et al., 1996; 
Number of neurons

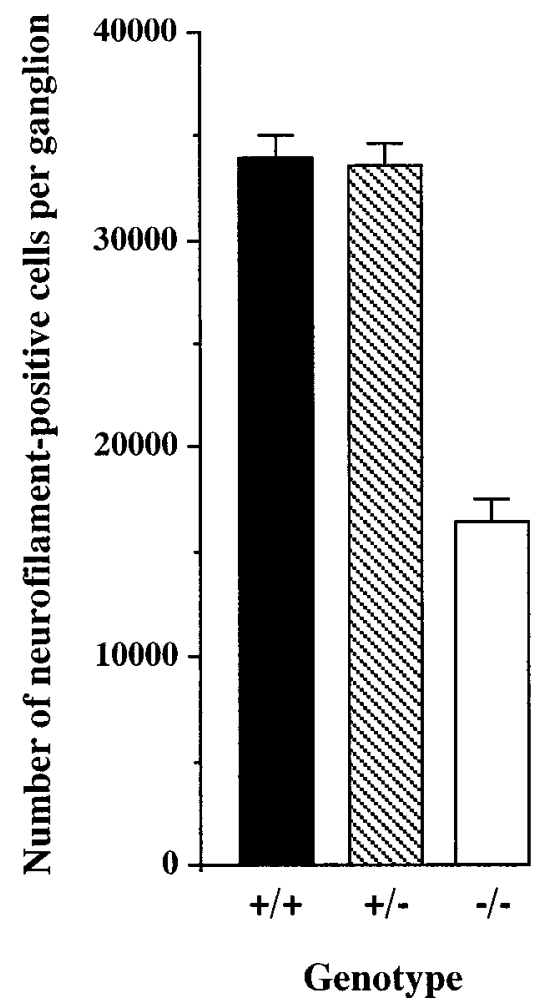

$\operatorname{trkC~TK+~mRNA~}$

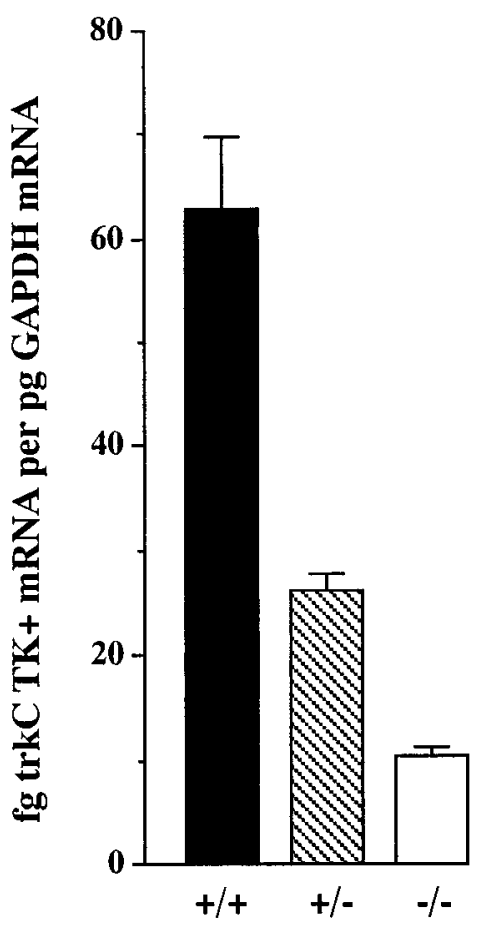

Genotype
trkC TK- mRNA

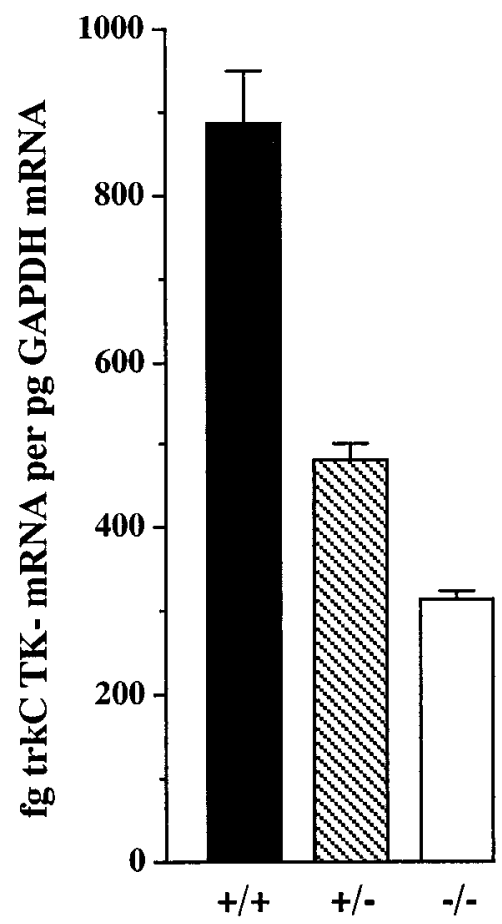

Genotype

Figure 4. Number of neurons and the levels of $\mathrm{TK}^{+}$and $\mathrm{TK}^{-}$trkC transcripts relative to GAPDH mRNA in the trigeminal ganglia of E14 NT3 ${ }^{+/+}$, $N T 3^{+-}$, and $N T 3^{-1-}$ embryos. The mean and SEM of measurements from the ganglia of between five and eight embryos of each genotype are shown.

Wilkinson et al., 1996) together with our demonstration that trkC is predominantly expressed in neurons suggests that the relativedecrease in trkC levels in the trigeminal ganglia of $N T 3^{-/-}$ embryos is caused at least in part by the loss of trkC-expressing neurons. To investigate if endogenous NT3 also regulates trkC expression in trigeminal neurons, we studied neuronal survival and trkC mRNA expression in the trigeminal ganglia of $N T 3^{+/-}$ embryos. The total number of neurons in the trigeminal ganglia of $N T 3^{+/+}, N T 3^{+/-}$, and $N T 3^{-/-}$embryos at E14 was estimated by counting neuronal profiles in $8 \mu \mathrm{m}$ serial sections and applying the Abercrombie correction for split nuclei. These estimates revealed no statistically significant difference in the numbers of neurons in the trigeminal ganglia of $N T 3^{+/+}$and $N T 3^{+/-}$embryos $(p>0.05 ; t$ test) and a twofold reduction in the number of trigeminal neurons in $N T 3^{-/-}$embryos (Fig. 4). In contrast, at the same stage of development, there were marked, statistically significant reductions in the levels of $\mathrm{TK}^{+}$trkC and $\mathrm{TK}^{-}$trkC mRNAs in the trigeminal ganglia of $N T 3^{+/-}$embryos relative to wild-type embryos ( $p<0.01$ in both cases; $t$ tests), and there were further reductions in the levels of these transcripts in the trigeminal ganglia of $\mathrm{NT3}^{-1-}$ embryos (Fig. 4). These reductions were most marked for $\mathrm{TK}^{+}$trkC mRNA; more than twofold in $N T 3^{+/-}$and sixfold in NT3 ${ }^{-1-}$ embryos compared with less than twofold in $N T 3^{+/-}$and threefold in $N T 3^{-/-}$embryos in the case of $\mathrm{TK}^{-}$trkC mRNA. Taken together, these results suggest that a reduction in the level of NT3 in $N T 3^{+/-}$embryos that is insufficient to affect neuron number results in a reduction in trkC
mRNA expression, implying that endogenous NT3 regulates trkC expression in neurons.

\section{Regulation of trkC expression in trigeminal neurons by NT3 in vitro}

To investigate further the role of NT3 in regulating trkC mRNA expression, we measured the level of trkC mRNA in trigeminal ganglion explants and low-density dissociated cultures of trigeminal neurons grown with and without NT3. These studies were undertaken at two ages: at E13, the earliest age at which there was a marked decrease in the levels of trkC transcripts relative to GAPDH mRNA in the trigeminal ganglia of $N T 3^{-/-}$embryos, and at E16 during the ongoing period of sustained reduction of trkC expression in $N T 3^{-1-}$ embryos. We focused on $\mathrm{TK}^{+}$trkC mRNA because the relative reduction of $\mathrm{TK}^{+}$trkC mRNA in $N T 3^{-1-}$ embryos was greater than that of $\mathrm{TK}^{-}$trkC mRNA. To maintain the survival of neurons in these experiments, NGF was added to all cultures.

In the absence of NT3, there was a fall in the level of $\mathrm{TK}^{+} \operatorname{trkC}$ mRNA relative to GAPDH mRNA in both dissociated and explant cultures (Fig. 5). The fall was most pronounced in dissociated cultures; there was a $>50 \%$ decrease within $3 \mathrm{hr}$ of plating, and by $24 \mathrm{hr}$ the levels were 15 -fold lower. In contrast, there was a more gradual decrease in the relative level of $\mathrm{TK}^{+}$trkC mRNA in E13 explants, decreasing by $37 \%$ after $24 \mathrm{hr}$ of incubation and $66 \%$ after $48 \mathrm{hr}$. The levels of $\mathrm{TK}^{+}$trkC mRNA were less well sustained in E16 explants, reaching the level observed in E16 dissociated cultures by $24 \mathrm{hr}$ of incubation. The decrease in the 


\section{E13}

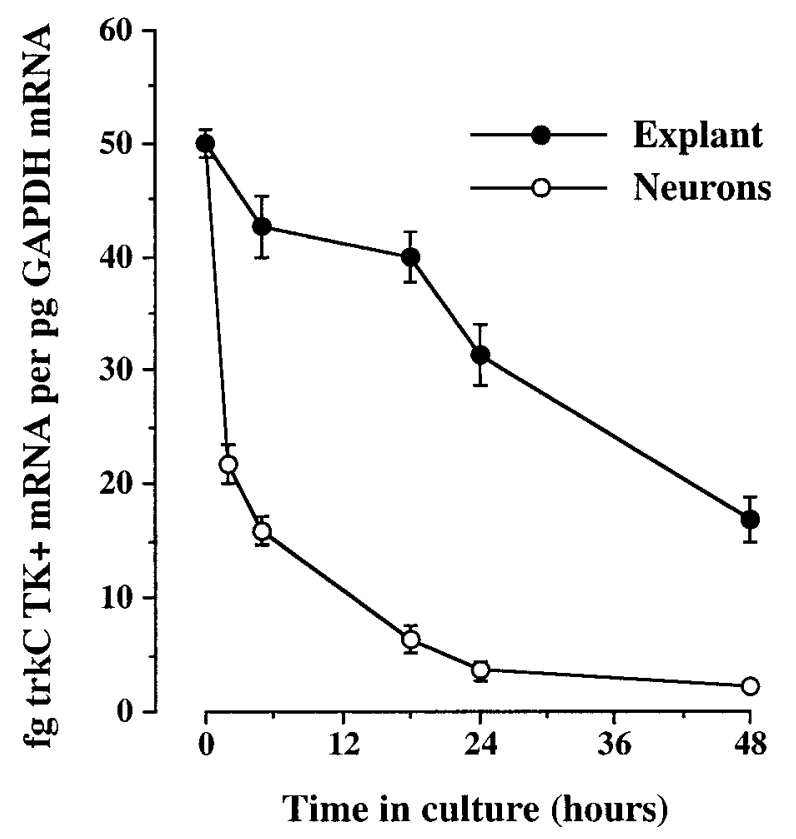

E16

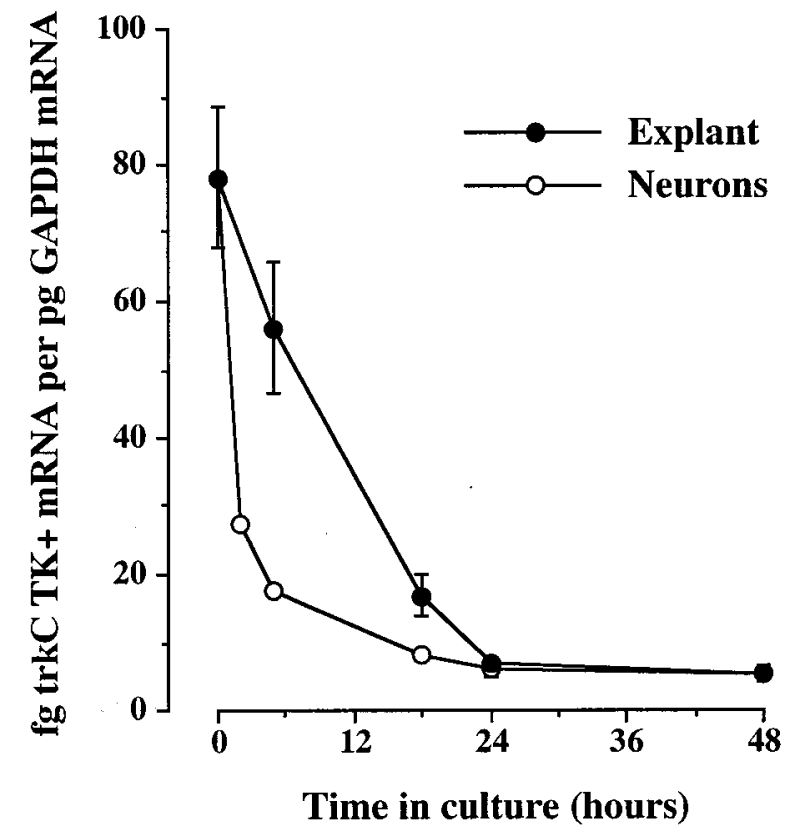

Figure 5. Levels of $\mathrm{TK}^{+}$trkC mRNA relative to GAPDH mRNA in explant and dissociated cultures of E13 and E16 trigeminal ganglia after different times in culture. Each data point represents the mean and SEM of four separate measurements.

relative level of $\mathrm{TK}^{+}$trkC mRNA in these cultures could not be explained by a marked decrease in the viability of the neurons because the majority of neurons in NGF-supplemented dissociated cultures survived throughout the period of study (percent survival after $48 \mathrm{hr}$ of incubation was $92 \pm 3.3 \%$ for E13 cultures and $90 \pm 7.0 \%$ for E16 cultures). Because the serum-free medium we used in the low-density dissociated cultures did not promote the proliferation or survival of non-neuronal cells, $>90 \%$ of the cells in these cultures were neurons by $48 \mathrm{hr}$ of incubation.

To investigate if exogenous NT3 could sustain or increase trkC mRNA expression in vitro, explants and low-density dissociated cultures of trigeminal ganglia were grown with NT3 over a range of concentrations. Figure 6 shows that NT3 affected $\mathrm{TK}^{+}$trkC mRNA expression in a dose-dependent manner. After $48 \mathrm{hr}$ of incubation, the level of $\mathrm{TK}^{+}$trkC mRNA in dissociated cultures containing NT3 at concentrations at and above $0.04 \mathrm{ng} / \mathrm{ml}$ was threefold to fourfold higher than in control cultures (no added NT3). Although the levels of trkC mRNA were higher in the presence of NT3, there was still an overall decrease in trkC mRNA levels by $48 \mathrm{hr}$ of incubation, indicating that NT3 alone is not sufficient to sustain trkC mRNA expression in cultured neurons. The effect of NT3 in these NGF-supplemented cultures could not be explained by differences in the number of surviving neurons because there were no additional surviving neurons in the presence of NT3. Very similar results were obtained if the trkC mRNA data were expressed relative to neuron number rather than GAPDH mRNA in the dissociated cultures in which the numbers of surviving neurons could be early ascertained (data not shown).

As in dissociated cultures, the level of $\mathrm{TK}^{+} \operatorname{trkC}$ mRNA in explants was higher in the presence of NT3 than in control cultures. However, the concentrations required to elevate trkC mRNA expression in explant cultures were much higher; whereas
$1 \mathrm{ng} / \mathrm{ml} \mathrm{NT3}$ was maximally effective in dissociated cultures, 50 $\mathrm{ng} / \mathrm{ml}$ was required in explant cultures, $1 \mathrm{ng} / \mathrm{ml}$ having no effect. This higher concentration of NT3 was able to sustain the expression of trkC mRNA in E13 explants, but did not fully prevent the decrease in trkC mRNA in E16 explants.

The slower decline in trkC mRNA expression in control trigeminal ganglion explants compared with trigeminal neurons in low-density control cultures suggests that a factor within the intact ganglion promotes trkC mRNA expression. Because NT3 is known to be synthesized within sensory ganglia (Schecterson and Bothwell, 1992; Zhang et al., 1994), we compared trkC mRNA levels in trigeminal ganglion explants from wild-type and $N T 3^{-1-}$ embryos. Figure 7 shows that there was a similar percentage decrease in the level of $\mathrm{TK}^{+}$trkC mRNA in E13 wildtype and NT3-/- trigeminal ganglion explants. These results suggest that ganglion-derived NT3 does not play a significant role in regulating trkC mRNA expression and that there are other factors within the ganglion that sustain trkC expression.

To determine whether the in vivo reduction in the level of trkC mRNA observed in the trigeminal ganglia of $N T 3^{+/-}$embryos (Fig. 4) is simply caused by reduced NT3 availability or whether the capacity of the neurons in these embryos to respond to NT3 is additionally compromised, we compared the ability of NT3 to regulate trkC mRNA expression in trigeminal ganglion explants from wild-type and $N T 3^{+/-}$embryos. Figures 8 and 9 show that after $24 \mathrm{hr}$ of incubation without NT3, the level of $\operatorname{trkC~TK}^{+}$in wild-type and $N T 3^{+/-}$ganglia fell to similar values. However, NT3 was equally effective in increasing the level of $\operatorname{trkC~} \mathrm{TK}^{+}$in trigeminal ganglion explants obtained from wild-type and $N T 3^{+/-}$embryos; the NT3 dose responses in both cases were very similar (Fig. 8). Because the trigeminal ganglia of wild-type and $N T 3^{+/-}$embryos contain very similar numbers of neurons (Fig. 4 ), these results clearly show that the capacity of trigeminal 


\section{Dissociated neurons}

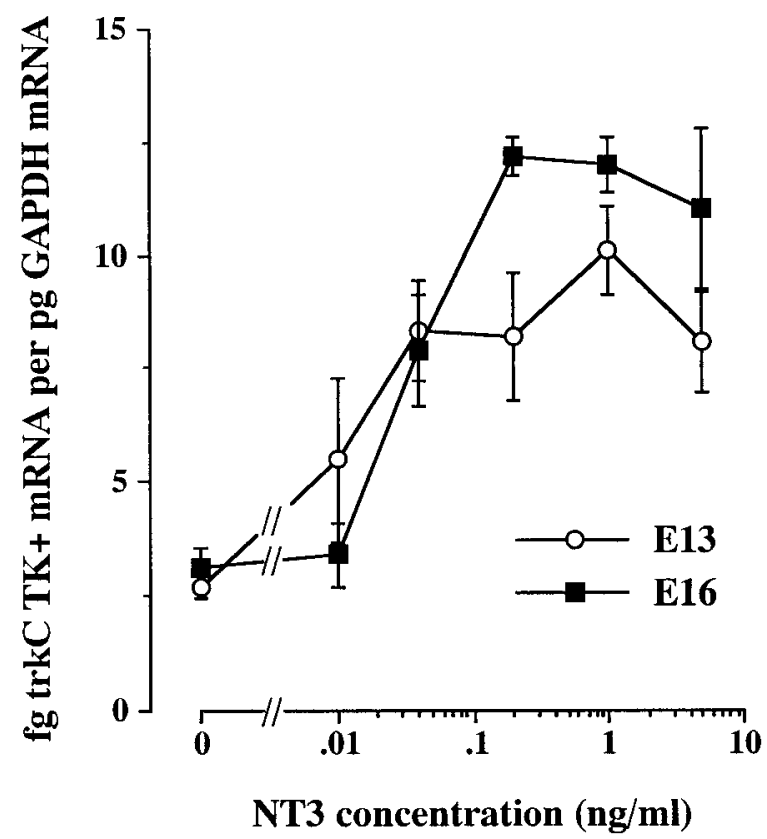

\section{Explant cultures}

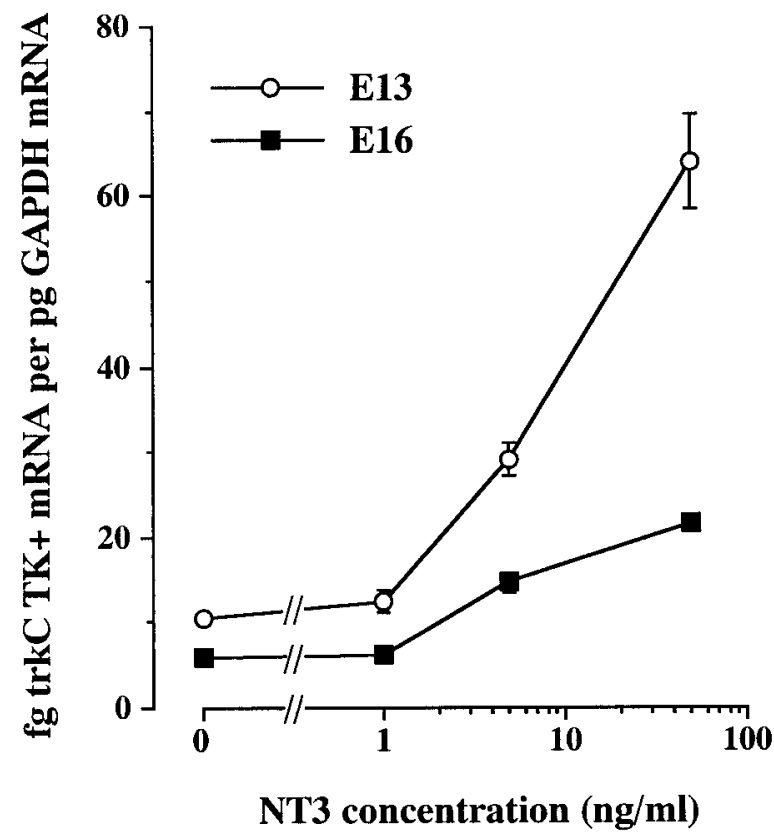

Figure 6. Levels of $\mathrm{TK}^{+}$trkC mRNA relative to GAPDH mRNA after $48 \mathrm{hr}$ in explant and dissociated cultures of E13 and E16 trigeminal ganglia supplemented with either NGF alone or NGF plus different concentrations of NT3. There was no further elevation in trkC mRNA at higher NT3 concentrations (data not shown). Each data point represents the mean and SEM of four separate measurements.

neurons to respond to NT3 is not compromised in $N T 3^{+/-}$ embryos and further strengthen our proposal that the reduction in trkC mRNA in vivo in these embryos is caused by the reduction in the in vivo availability of NT3.

\section{trkC expression in sympathetic neurons is not increased by NT3}

To investigate if NT3 affects the expression of trkC mRNA in developing sympathetic neurons, we measured the level of trkC mRNA in the SCG of wild-type and NT3 ${ }^{-1-}$ embryos and in SCG explants and dissociated cultures grown with and without NT3. There was no significant difference in the levels of $\mathrm{TK}^{+}$and $\mathrm{TK}^{-}$ trkC transcripts relative to GAPDH mRNA between wild-type and $N T 3^{-1-}$ SCG at E14 when the SCG consists predominantly of proliferating sympathetic neuroblasts and later in development at E18 when the SCG contains postmitotic sympathetic neurons that are mostly dependent on NGF and NT3 for survival $(p>$ 0.05 in both cases; $t$ tests; Fig. 9). There was no significant difference in the level of $\mathrm{TK}^{+}$trkC mRNA between control E13 SCG explants and explants grown with NT3 over a range of NT3 concentrations ( $p>0.05$; $t$ test; Fig. 10). In dissociated cultures, rather than increasing trkC mRNA expression, NT3 caused a small, statistically significant ( $p<0.05 ; t$ test), dose-dependent decrease in $\mathrm{TK}^{+}$trkC mRNA. Counts of viable neurons in these NGF-containing cultures after $48 \mathrm{hr}$ of incubation revealed no effect of NT3 on survival ( $70 \pm 2.4 \%$ with NGF vs $64 \pm 3.5 \%$ with NGF plus $50 \mathrm{ng} / \mathrm{ml} \mathrm{NT3).} \mathrm{Thus,} \mathrm{in} \mathrm{contrast} \mathrm{to} \mathrm{developing} \mathrm{trigem-}$ inal neurons, NT3 does not upregulate trkC mRNA expression in developing sympathetic neuroblasts and neurons.

\section{trkC expression in cutaneous tissue is not regulated} by NT3

Low levels of $\mathrm{TK}^{-}$trkC mRNA are expressed in the cutaneous tissues innervated by the trigeminal ganglion during develop- ment. To investigate if endogenous NT3 affects the expression of trkC mRNA in these tissues, we measured the levels of $\mathrm{TK}^{-}$trkC mRNA in the whiskerpads of wild-type and NT3 ${ }^{-1-}$ embryos because this is the part of the trigeminal territory that expresses the highest levels of NT3 during development (Buchman et al., 1993, 1994). Figure 11 shows that very similar levels of $\mathrm{TK}^{-}$trkC mRNA were expressed in the whiskerpads of wild-type and $N T 3^{-1-}$ embryos at stages ranging from E12 to $\mathrm{P} 0$, indicating that endogenous NT3 does not affect the expression of trkC mRNA in developing skin.

\section{DISCUSSION}

We have shown for the first time that physiological levels of a neurotrophin regulate the expression of transcripts encoding its cognate trk receptor in vivo. The levels of both $\mathrm{TK}^{+}$and $\mathrm{TK}^{-}$ trkC transcripts in developing trigeminal neurons are much lower in mouse embryos that have a null mutation in the NT3 gene than in wild-type embryos. Importantly, markedly lower levels of trkC mRNA are evident in heterozygous embryos at a stage in development when there is no loss of trigeminal neurons. This indicates that the reduction in trkC mRNA is not simply caused by the loss of a trkC-expressing, NT3-dependent subset of neurons but that endogenous levels of NT3 are limiting for trkC mRNA expression in these neurons. Previous studies of the effects of supraphysiological levels of NGF in vivo and NGF and BDNF in vitro have shown that these neurotrophins can increase expression of their corresponding Trk receptor and the common neurotrophin receptor p75 (Doherty et al., 1988; Cavicchioli et al., 1989; Higgins et al., 1989; Lindsay et al., 1990; Fusco et al., 1991; Miller et al., 1991, 1994; Holtzman et al., 1992; Kojima et al., 1992; Verge et al., 1992; Wyatt and Davies, 1993, 1995; Kojima et al., 1994; Sohrabji et al., 1994; Venero et al., 1994; Verdi and Ander- 
A

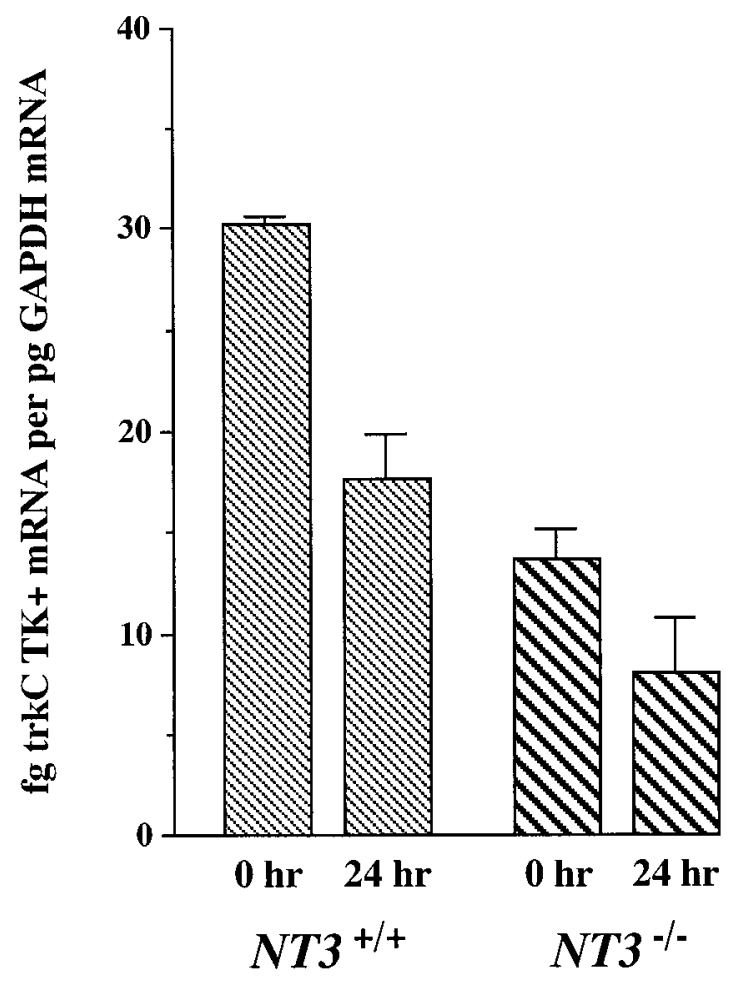

B

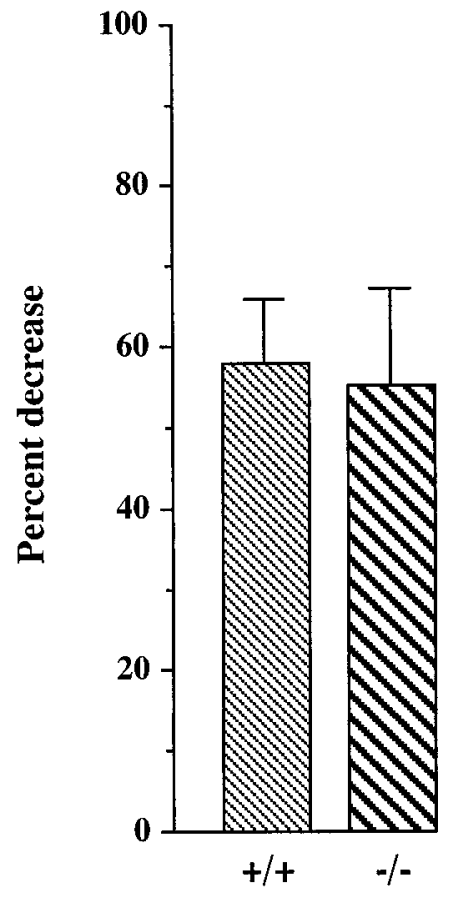

Figure 7. $A$, Levels of $\mathrm{TK}^{+}$trkC mRNA relative to GAPDH mRNA in E13 trigeminal ganglia from $N T 3^{+/+}$and $N T 3^{-/-}$embryos immediately after dissection $(0 \mathrm{hr})$ and after $24 \mathrm{hr}$ of incubation with NGF. $B$, Percentage decrease in the relative levels of $\mathrm{TK}^{+}$trkC mRNA between 0 and $24 \mathrm{hr}$ in trigeminal explants from $N T 3^{+/+}$and $N T 3^{-1-}$ embryos. The mean and SEM of four explants of each genotype at each time point are shown.

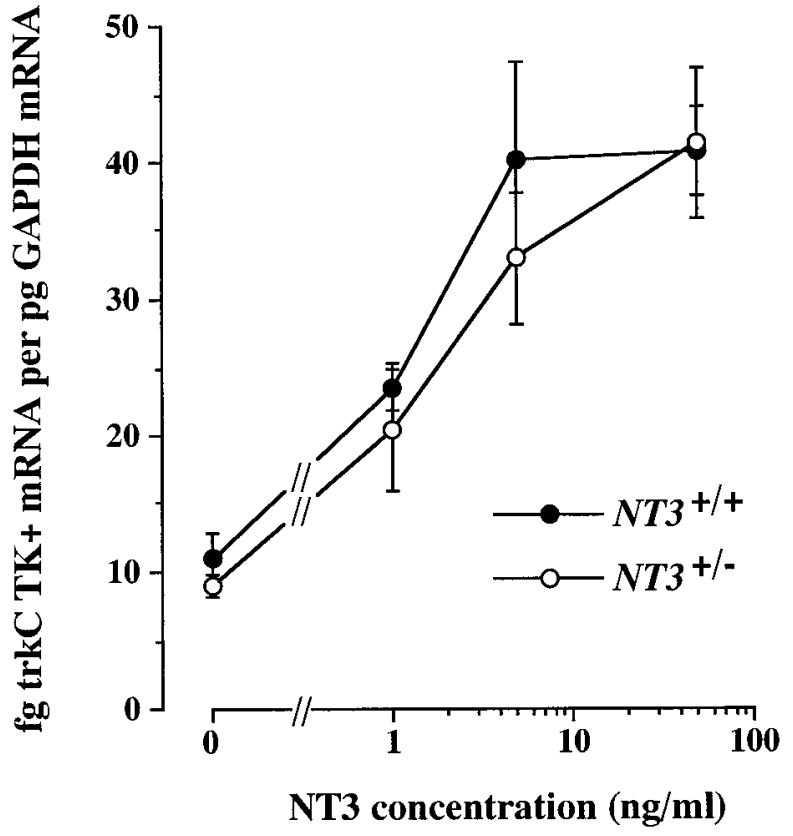

Figure 8. Levels of $\mathrm{TK}^{+}$trkC mRNA relative to GAPDH mRNA in E13 trigeminal ganglia from $N T 3^{+/+}$and $N T 3^{+/-}$embryos immediately after dissection $(0 \mathrm{hr})$ and when grown as explants for $48 \mathrm{hr}$ with different concentrations of NT3. The mean and SEM of three to nine explants of each genotype at each time point are shown.

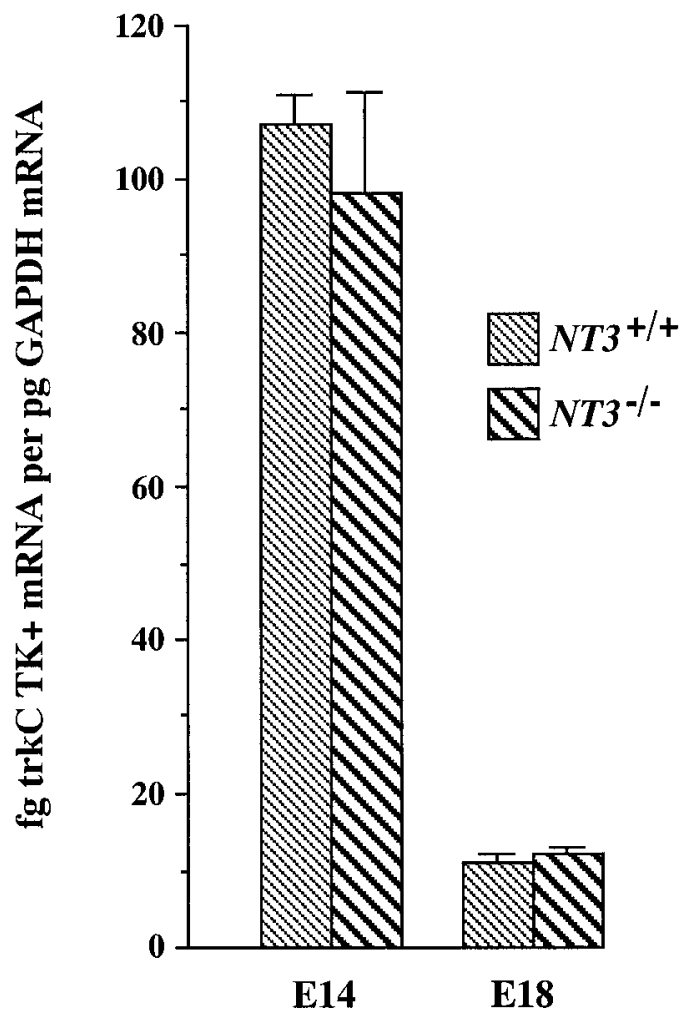

Figure 9. Levels of $\mathrm{TK}^{+}$trkC mRNA relative to GAPDH mRNA in E14 and E18 SCG from $N T 3^{+/+}$and $N T 3^{-/-}$embryos. The mean and SEM of measurements taken from the SCGs of between four and seven embryos of each age and genotype are shown. 


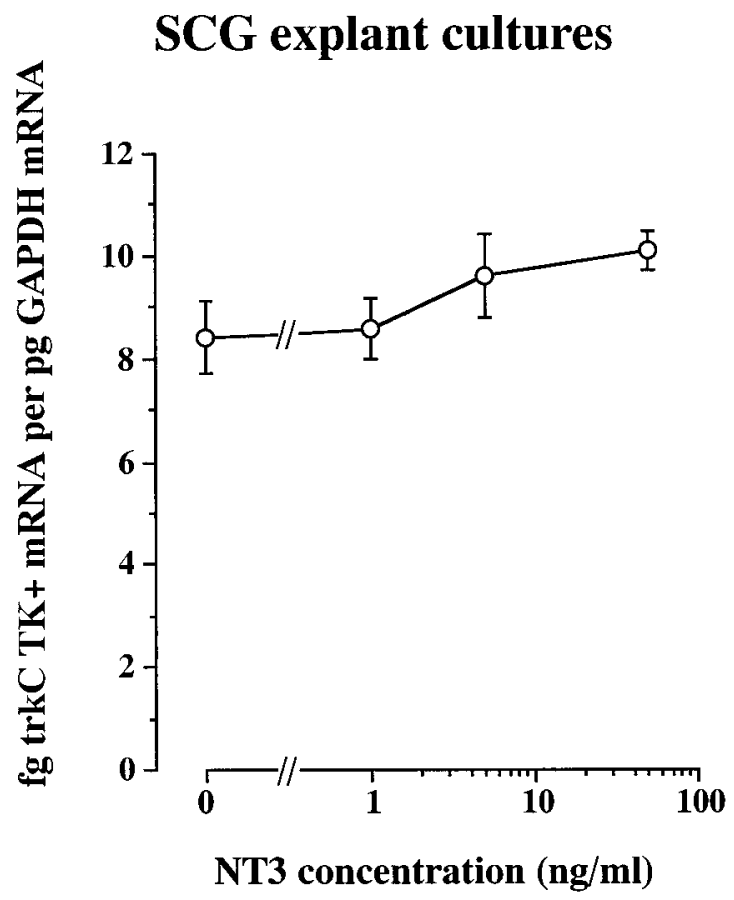

\section{SCG dissociated cultures}

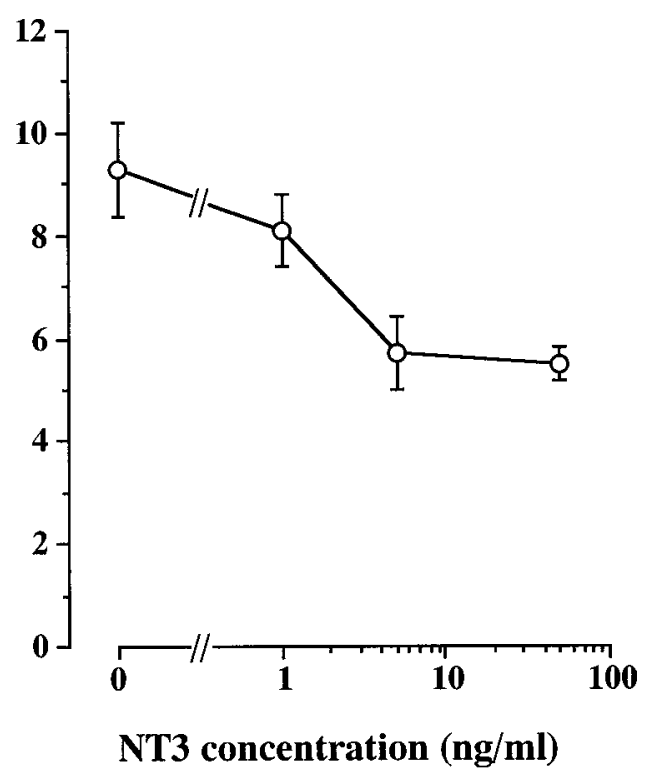

Figure 10. Levels of $\mathrm{TK}^{+}$trkC mRNA relative to GAPDH mRNA after $48 \mathrm{hr}$ in explant and dissociated cultures of E13 SCG supplemented with either NGF alone or NGF plus different concentrations of NT3. Each data point represents the mean and SEM of four separate measurements.

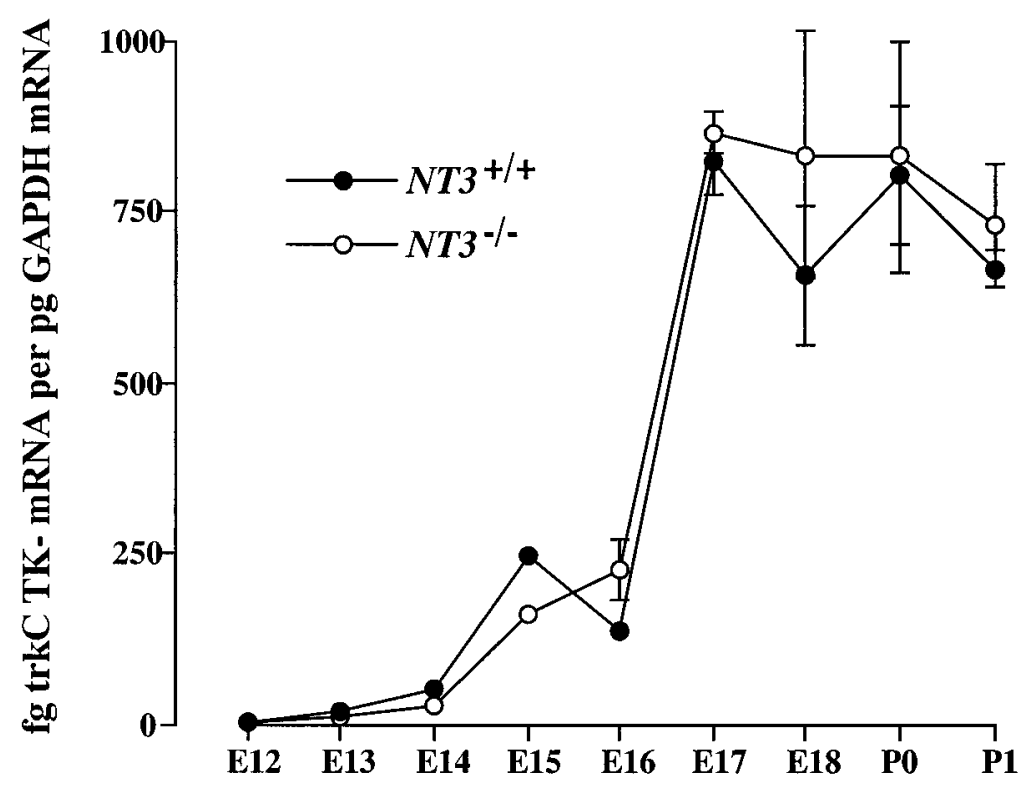

Embryonic age
Figure 11. Levels of $\mathrm{TK}^{-}$trkC mRNA relative to GAPDH mRNA in the whiskerpads of E12 to P1 $N T 3^{+/+}$and $N T 3^{-1-}$ mice. The mean and SEM of measurements from the whiskerpads of three separate animals of each genotype at each stage are shown. son, 1994; Ninkina et al., 1996). However, the developmental increase in TrkA and p75 in sensory neurons occurs normally in $N G F^{-/-}$embryos (Davies et al., 1995b), indicating that endogenous NGF does not regulate NGF receptor expression in sensory neurons during the early stages of their development in vivo. Likewise, the developmental increase in the expression of both $\mathrm{TK}^{+}$and $\mathrm{TK}^{-}$trkB transcripts in sensory neurons occurs normally in $B D N F^{-1-}$ embryos (Huber, Wyatt, and Davies, unpublished results). Thus, endogenous NT3 appears to be unique in being able to regulate the expression of its cognate trk receptor in developing sensory neurons.
Although we have clearly shown that endogenous NT3 regulates the expression of trkC transcripts in developing sensory neurons, NT3 is not the only factor involved in regulating trkC expression in vivo. The levels of trkC initially increase normally in the trigeminal ganglia of $N T 3^{-/-}$embryos and only fall below the level in wild-type embryos after E12, indicating that NT3 is not required for the initial induction of trkC expression. Although NT3 increases trkC mRNA levels in trigeminal neurons placed in culture during the stages of development when endogenous NT3 plays a role in regulating trkC mRNA expression in vivo, the levels of trkC mRNA in these cultures are not sustained at in vivo 
levels even in the presence of NT3. This suggests that NT3 is not the sole factor regulating trkC expression at these later stages of development. The finding that trkC mRNA levels are more sustained in trigeminal ganglion explants than in dissociated cultures suggests that factors within the ganglion play a role in sustaining trkC expression. Our demonstration that trkC mRNA levels are similar in explants from $N T 3^{-1-}$ and wild-type embryos excludes the possibility that NT3 synthesized within the ganglion accounts for this difference in trkC expression between explant and dissociated cultures.

In marked contrast to developing sensory neurons, NT3 does not influence trkC mRNA expression in either sympathetic neurons or developing cutaneous tissues. Not only is trkC mRNA expressed at normal levels in the sympathetic neurons of NT3 ${ }^{-1-}$ embryos throughout development, trkC mRNA expression is not increased by NT3 treatment in either dissociated or explant cultures of sympathetic neurons. Likewise, the level of trkC mRNA increases normally in the whiskerpads of $N T 3^{-1-}$ embryos throughout development. These results demonstrate that endogenous NT3 regulates trkC mRNA expression in a highly cell-selective manner.

In addition to the different ways in which trkC mRNA expression is controlled in developing trigeminal and sympathetic neurons, we have shown that there are striking differences in the developmental time course of trkC mRNA expression in these two kinds of neurons. Whereas the level of trkC mRNA is high in sympathetic neuroblasts and declines markedly in postmitotic sympathetic neurons (Wyatt et al., 1997), the level of trkC mRNA increases markedly in trigeminal neurons during development (present study). Although trkC $\mathrm{TK}^{-}$transcripts greatly outnumber $\mathrm{TK}^{+}$transcripts in both kinds of neurons, there are differences in the ratio between these transcripts during the development. Whereas the ratio remains similar throughout trigeminal neuron development, the relative level of $\mathrm{TK}^{+}$trkC decreases markedly during sympathetic neuron development, becoming negligible by E18 (Wyatt et al., 1997). The functional significance of these different patterns of trkC mRNA expression is unclear as studies of $t r k C^{-/-}$and $N T 3^{-/-}$mice suggest that trkC does not play a significant role in mediating the in vivo survival requirement of trigeminal and sympathetic neurons for NT3. Although there are substantial losses of trigeminal and sympathetic neurons in NT3 ${ }^{-1-}$ embryos (ElShamy and Ernfors, 1996b; Wilkinson et al., 1996; Wyatt et al., 1997), there is negligible loss of these neurons in trkC $C^{-1-}$ embryos (Fagan et al., 1996; Piñón et al., 1996). NT3 can, however, promote the in vitro survival of developing sympathetic and trigeminal neurons by signaling via trk receptors other than trkC (Davies et al., 1995a), suggesting that the in vivo dependence of these neurons is mediated by trkA or trkB. Likewise, recent studies of the numbers of trkA-, trkB-, and trkC-immunoreactive neurons in the dorsal root and trigeminal ganglia of $N T 3^{-/-}$embryos have also shown that NT3 activates more than one trk receptor in developing sensory neurons (Farinas et al., 1998; Huang et al., 1999). However, our current study suggests that the virtual elimination of trkC-immunoreactive neurons observed in the dorsal root and trigeminal ganglia of $N T 3^{-1-}$ embryos (Farinas et al., 1998; Huang et al., 1999) may not be caused entirely by the death of these neurons but to a decrease in trkC expression in the absence of endogenous NT3.

Perhaps the effect of endogenous NT3 on upregulating and/or sustaining trkC expression could be an important step in the development of a functionally distinct subset of sensory neurons such as proprioceptive neurons, which are absent in both NT3 ${ }^{-1-}$ and $\mathrm{trk}^{-/-}$embryos. In this respect, the selective action of endogenous NT3 on trkC expression could be serving an instructive and/or permissive role in sensory neuron development. In contrast, endogenous NGF and BDNF, which do not regulate the expression of their cognate trk receptors in vivo, primarily influence the neuronal composition of sensory ganglia by promoting the survival of subsets of neurons that express trkA or trkB irrespective of whether they have been exposed to these neurotrophins.

In summary, we have shown that the strikingly different patterns of trkC expression in developing sympathetic and sensory neurons are selectively regulated by NT3 in vivo. Whereas endogenous NT3 increases trkC expression in sensory neurons, it plays no obvious role in regulating trkC expression in sympathetic neurons. This is the first clear demonstration that physiological levels of a neurotrophin in vivo play a role in regulating the expression of the gene encoding its cognate trk receptor and show that this mechanism of regulation only occurs in a subset of cells expressing the receptor.

\section{REFERENCES}

Armanini MP, McMahon SB, Sutherland J, Shelton DL, Phillips HS (1995) Truncated and catalytic isoforms of trkB are co-expressed in neurons of rat and mouse CNS. Eur J Neurosci 7:1403-1409.

Beck KD, Lamballe F, Klein R, Barbacid M, Schauwecker PE, McNeill TH, Finch CE, Hefti F, Day JR (1993) Induction of noncatalytic TrkB neurotrophin receptors during axonal sprouting in the adult hippocampus. J Neurosci 13:4001-4014.

Benedetti M, Levi A, Chao MV (1993) Differential expression of nerve growth factor receptors leads to altered binding affinity and neurotrophin responsiveness. Proc Natl Acad Sci USA 90:7859-7863.

Berkemeier LR, Winslow JW, Kaplan DR, Nikolics K, Goeddel DV, Rosenthal A (1991) Neurotrophin-5: a novel neurotrophic factor that activates trk and trkB. Neuron 7:857-866.

Biffo S, Offenhauser N, Carter BD, Barde YA (1995) Selective binding and internalisation by truncated receptors restrict the availability of BDNF during development. Development 121:2461-2470.

Bothwell M (1995) Functional interactions of neurotrophins and neurotrophin receptors. Annu Rev Neurosci 18:223-253.

Buchman VL, Davies AM (1993) Different neurotrophins are expressed and act in a developmental sequence to promote the survival of embryonic sensory neurons. Development 118:989-1001.

Buchman VL, Sporn M, Davies AM (1994) Role of transforming growth factor- $\beta$ isoforms in regulating the expression of nerve growth factor and neurotrophin-3 mRNA levels in embryonic cutaneous cells at different stages of development. Development 120:1621-1629.

Casaccia-Bonnefil P, Carter BD, Dobrowsky RT, Chao MV (1996) Death of oligodendrocytes mediated by the interaction of nerve growth factor with its receptor p75. Nature 383:716-719.

Cavicchioli L, Flanigan TP, Vantini G, Fusco M, Polato P, Toffano G, Walsh FS, Leon A (1989) NGF amplifies expression of NGF receptor messenger RNA in forebrain cholinergic neurons of rats. Eur J Neurosci $1: 258-262$.

Clary DO, Reichardt LF (1994) An alternatively spliced form of the nerve growth factor receptor TrkA confers an enhanced response to neurotrophin-3. Proc Natl Acad Sci USA 91:11133-11137.

Coughlin MD, Collins MB (1985) Nerve growth factor-independent development of embryonic mouse sympathetic neurons in dissociated cell culture. Dev Biol 110:392-401.

Davey F, Davies AM (1998) TrkB signalling inhibits p75-mediated apoptosis induced by NGF in embryonic proprioceptive neurons. Curr Biol 8:915-918.

Davies AM (1986) The survival and growth of embryonic proprioceptive neurons is promoted by a factor present in skeletal muscle. Dev Biol 115:56-67.

Davies AM (1994) Role of neurotrophins in the developing nervous system. J Neurobiol 25:1334-1348.

Davies AM (1997) Neurotrophin switching: where does it stand. Curr Opin Neurobiol 7:110-118.

Davies AM, Lumsden AGS (1984) Relation of target encounter and 
neuronal death to nerve growth factor responsiveness in the developing mouse trigeminal ganglion. J Comp Neurol 223:124-137.

Davies AM, Lee KF, Jaenisch R (1993) p75-deficient trigeminal sensory neurons have an altered response to NGF but not to other neurotrophins. Neuron 11:565-574.

Davies AM, Minichiello L, Klein R (1995a) Developmental changes in NT3 signalling via TrkA and TrkB in embryonic neurons. EMBO J 14:4482-4489.

Davies AM, Wyatt S, Nishimura M, Phillips H (1995b) NGF receptor expression in sensory neurons develops normally in embryos lacking NGF. Dev Biol 171:434-438.

Doherty P, Seaton P, Flanigan TP, Walsh FS (1988) Factors controlling the expression of the NGF receptor in PC12 cells. Neurosci Lett 92:222-227.

ElShamy WM, Ernfors P (1996a) A local action of neurotrophin-3 prevents the death of proliferating sensory neuron precursor cells. Neuron 16:963-972.

ElShamy WM, Ernfors P (1996b) Requirement of neurotrophin-3 for the survival of proliferating trigeminal ganglion progenitor cells. Development 122:2405-2414.

Ernfors P, Lee KF, Kucera J, Jaenisch R (1994) Lack of neurotrophin-3 leads to deficiencies in the peripheral nervous system and loss of limb proprioceptive afferents. Cell 77:503-512.

Ernsberger U, Edgar D, Rohrer H (1989) The survival of early chick sympathetic neurons in vitro is dependent on a suitable substrate but independent of NGF. Dev Biol 135:250-262.

Fagan AM, Zhang H, Landis S, Smeyne RJ, Silos-Santiago I, Barbacid M (1996) TrkA, but not trkC, receptors are essential for survival of sympathetic neurons in vivo. J Neurosci 16:6208-6218.

Farinas I, Yoshida CK, Backus C, Reichardt LF (1996) Lack of neurotrophin-3 results in death of spinal sensory neurons and premature differentiation of their precursors. Neuron 17:1065-1078.

Farinas I, Wilkinson GA, Backus C, Reichardt LF, Patapoutian A (1998) Characterization of neurotrophin and Trk receptor functions in developing sensory ganglia: direct NT-3 activation of TrkB neurons in vivo. Neuron 21:325-334.

Frade JM, Rodriguez-Tebar A, Barde YA (1996) Induction of cell death by endogenous nerve growth factor through its p75 receptor. Nature 383:166-168.

Frisen J, Verge VM, Fried K, Risling M, Persson H, Trotter J, Lindholm D (1993) Characterisation of glia trkB receptors: differential response to injury in the central and peripheral nervous systems. Proc Natl Acad Sci USA 90:4971-4975.

Funakoshi H, Frisen J, Barbany G, Timmusk T, Zachrisson O, Verge VM, Persson H (1993) Differential expression of mRNAs for neurotrophins and their receptors after axotomy of the sciatic nerve. J Cell Biol 123:455-465.

Fusco M, Polato P, Vantini G, Cavicchioli L, Bentivoglio M, Leon A (1991) Nerve growth factor differentially modulates the expression of its receptor within the CNS. J Comp Neurol 312:477-491.

Glass DJ, Nye SH, Hantzopoulos P, Macchi MJ, Squinto SP, Goldfarb M, Yancopoulos GD (1991) TrkB mediates BDNF/NT-3-dependent survival and proliferation in fibroblasts lacking the low affinity NGF receptor. Cell 66:405-413.

Hempstead BL, Martin ZD, Kaplan DR, Parada LF, Chao MV (1991) High-affinity NGF binding requires coexpression of the trk protooncogene and the low-affinity NGF receptor. Nature 350:678-683.

Higgins GA, Koh S, Chen KS, Gage FH (1989) NGF induction of NGF receptor gene expression and cholinergic neuronal hypertrophy within the basal forebrain of the adult rat. Neuron 3:247-256.

Holtzman DM, Li Y, Parada LF, Kinsman S, Chen CK, Valletta JS, Zhou J, Long JB, Mobley WC (1992) p140trk mRNA marks NGFresponsive forebrain neurons: evidence that trk gene expression is induced by NGF. Neuron 9:465-478.

Horton AR, Laramee G, Wyatt S, Shih A, Winslow J, Davies AM (1997) NGF binding to $\mathrm{p} 75$ enhances the sensitivity of sensory and sympathetic neurons to NGF at different stages of development. Mol Cell Neurosci 10:162-172.

Huang EJ, Wilkinson GA, Farinas I, Backus C, Zang K, Wong SL, Reichardt LF (1999) Expression of Trk receptors in the developing mouse trigeminal ganglion: in vivo evidence for NT-3 activation of TrkA and TrkB in addition to TrkC. Development 126:2191-2203.

Ip NY, Ibanez CF, Nye SH, McClain J, Jones PF, Gies DR, Belluscio L, Le BM, Espinosa RD, Squinto SP, Persson H, Yancopoulos GD (1992) Mammalian neurotrophin-4: structure, chromosomal localization, tis- sue distribution, and receptor specificity. Proc Natl Acad Sci USA 89:3060-3064.

Ip NY, Stitt TN, Tapley P, Klein R, Glass DJ, Fandl J, Greene LA, Barbacid M, Yancopoulos GD (1993) Similarities and differences in the way neurotrophins interact with the Trk receptors in neuronal and nonneuronal cells. Neuron 10:137-149.

Kaplan DR, Martin ZD, Parada LF (1991) Tyrosine phosphorylation and tyrosine kinase activity of the trk proto-oncogene product induced by NGF. Nature 350:158-160.

Klein R, Conway D, Parada LF, Barbacid M (1990a) The trkB tyrosine protein kinase gene codes for a second neurogenic receptor that lacks the catalytic kinase domain. Cell 61:647-656.

Klein R, Martin ZD, Barbacid M, Parada LF (1990b) Expression of the tyrosine kinase receptor gene trkB is confined to the murine embryonic and adult nervous system. Development 109:845-850.

Klein R, Jing SQ, Nanduri V, O'Rourke E, Barbacid M (1991a) The trk proto-oncogene encodes a receptor for nerve growth factor. Cell 65:189-197.

Klein R, Nanduri V, Jing SA, Lamballe F, Tapley P, Bryant S, Cordon CC, Jones KR, Reichardt LF, Barbacid M (1991b) The trkB tyrosine protein kinase is a receptor for brain-derived neurotrophic factor and neurotrophin-3. Cell 66:395-403.

Klein R, Silos SI, Smeyne RJ, Lira SA, Brambilla R, Bryant S, Zhang L, Snider WD, Barbacid M (1994) Disruption of the neurotrophin-3 receptor gene trkC eliminates la muscle afferents and results in abnormal movements. Nature 368:249-251.

Kojima M, Takahashi N, Ikeuchi T, Hatanaka H (1992) Nerve growth factor (NGF)-mediated up-regulation of low-affinity NGF receptor gene expression in cultured basal forebrain cholinergic neurons from postnatal 3-day-old rats. Mol Brain Res 16:267-273.

Kojima M, Ikeuchi T, Hatanaka H (1994) Nerve growth factor induces trkA mRNA expression in cultured basal forebrain cholinergic neurons from 17-day fetal rats. Neurosci Lett 169:47-50.

Lamballe F, Klein R, Barbacid M (1991) trkC, a new member of the trk family of tyrosine protein kinases, is a receptor for neurotrophin-3. Cell 66:967-979.

Lamballe F, Tapley P, Barbacid M (1993) trkC encodes multiple neurotrophin-3 receptors with distinct biological properties and substrate specificities. EMBO J 12:3083-3094.

Lee KF, Davies AM, Jaenisch R (1994) p75-deficient embryonic dorsal root sensory and neonatal sympathetic neurons display a decreased sensitivity to NGF. Development 120:1027-1033.

Lewin GR, Barde YA (1996) The physiology of neurotrophins. Annu Rev Neurosci 19:289-317.

Lindsay RM, Shooter EM, Radeke MJ, Misko TP, Dechant G, Thoenen H, Lindholm D (1990) Nerve growth factor regulates expression of the nerve growth factor receptor gene in adult sensory neurons. Eur J Neurosci 2:389-396.

Merlio JP, Ernfors P, Jaber M, Persson H (1992) Molecular cloning of rat trkC and distribution of cells expressing messenger RNAs for members of the trk family in the rat central nervous system. Neuroscience 51:513-532.

Miller FD, Mathew TC, Toma JG (1991) Regulation of nerve growth factor receptor gene expression by nerve growth factor in the developing peripheral nervous system. J Cell Biol 112:303-312.

Miller FD, Speelman A, Mathew TC, Fabian J, Chang E, Pozniak C, Toma JG (1994) Nerve growth factor derived from terminals selectively increases the ratio of p75 to trkA NGF receptors on mature sympathetic neurons. Dev Biol 161:206-217.

Ninkina N, Adu J, Fischer A, Pinon LG, Buchman VL, Davies AM (1996) Expression and function of TrkB variants in developing sensory neurons. EMBO J 15:6385-6393.

Paul G, Davies AM (1995) Trigeminal sensory neurons require extrinsic signals to switch neurotrophin dependence during the early stages of target field innervation. Dev Biol 171:590-605.

Piñón LGP, Minichiello L, Klein R, Davies AM (1996) Timing of neuronal death in $\operatorname{trk} A, \operatorname{trk} B$ and $\operatorname{trk} C$ mutant embryos reveals developmental changes in sensory neuron dependence on Trk signalling. Development 122:3255-3261.

Robinson M, Adu J, Davies AM (1996) Timing and regulation of trkB and $B D N F$ mRNA expression in placode-derived sensory neurons and their targets. Eur J Neurosci 8:2399-2406. 
Rudge JS, Li Y, Pasnikowski EM, Mattsson K, Pan L, Yancopoulos GD, Wiegand SJ, Lindsay RM, Ip NY (1994) Neurotrophic factor receptors and their signal transduction capabilities in rat astrocytes. Eur J Neurosci 6:693-705.

Ryden M, Murray-Rust J, Glass D, Ilag LL, Trupp M, Yancopoulos GD, McDonald NQ, Ibanez CF (1995) Functional analysis of mutant neurotrophins deficient in low-affinity binding reveals a role for p75LNGFR in NT-4 signalling. EMBO J 14:1979-1990.

Ryden M, Hempstead B, Ibanez CF (1997) Differential modulation of neuron survival during development by nerve growth factor binding to the p75 neurotrophin receptor. J Biol Chem 272:16322-16328.

Schecterson LC, Bothwell M (1992) Novel roles for neurotrophins are suggested by BDNF and NT-3 mRNA expression in developing neurons. Neuron 9:449-463.

Schimmang T, Minichiello L, Vazquez E, Joac IS, Giraldez F, Klein R, Represa J (1995) Developing inner ear sensory neurons require TrkB and TrkC receptors for innervation of their peripheral targets. Development 121:3381-3391.

Schneider R, Schweiger M (1991) A novel modular mosaic of cell adhesion motifs in the extracellular domains of the neurogenic trk and trkB tyrosine kinase receptors. Oncogene 6:1807-1811.

Snider WD (1994) Functions of the neurotrophins during nervous system development: what the knockouts are teaching us. Cell 77:627-638.

Sohrabji F, Greene LA, Miranda RC, Toran-Allerand CD (1994) Reciprocal regulation of estrogen and NGF receptors by their ligands in PC12 cells. J Neurobiol 25:974-988.

Soppet D, Escandon E, Maragos J, Middlemas DS, Reid SW, Blair J, Burton LE, Stanton BR, Kaplan DR, Hunter T, Nikolics K, Parada LF (1991) The neurotrophic factors brain-derived neurotrophic factor and neurotrophin-3 are ligands for the trkB tyrosine kinase receptor. Cell 65:895-903.

Squinto SP, Stitt TN, Aldrich TH, Davis S, Bianco SM, Radziejewski C, Glass DJ, Masiakowski P, Furth ME, Valenzuela DM, DiStefano PS, Yancopoulos GD (1991) trkB encodes a functional receptor for brainderived neurotrophic factor and neurotrophin-3 but not nerve growth factor. Cell 65:885-893.

Theiler K (1972) The house mouse (development and normal stages from fertilisation to 4 weeks). Berlin: Springer.

Tsoulfas P, Soppet D, Escandon E, Tessarollo L, Mendoza RJ, Rosenthal A, Nikolics K, Parada LF (1993) The rat trkC locus encodes multiple neurogenic receptors that exhibit differential response to neurotrophin-3 in PC12 cells. Neuron 10:975-990.

Valenzuela DM, Maisonpierre PC, Glass DJ, Rojas E, Nunez L, Kong Y, Gies DR, Stitt TN, Ip NY, Yancopoulos GD (1993) Alternative forms of rat TrkC with different functional capabilities. Neuron 10:963-974.

Van der Zee CE, Ross GM, Riopelle RJ, Hagg T (1996) Survival of cholinergic forebrain neurons in developing p75NGFR-deficient mice. Science 274:1729-1732.

Venero JL, Knusel B, Beck KD, Hefti F (1994) Expression of neurotrophin and trk receptor genes in adult rats with fimbria transections: effect of intraventricular nerve growth factor and brain-derived neurotrophic factor administration. Neuroscience 59:797-815.

Verdi JM, Anderson DJ (1994) Neurotrophins regulate sequential changes in neurotrophin receptor expression by sympathetic neuroblasts. Neuron 13:1359-1372.

Verge VM, Merlio JP, Grondin J, Ernfors P, Persson H, Riopelle RJ, Hokfelt T, Richardson PM (1992) Colocalization of NGF binding sites, trk mRNA, and low-affinity NGF receptor mRNA in primary sensory neurons: responses to injury and infusion of NGF. J Neurosci 12:4011-4022.

Wilkinson GA, Fariñas I, Backus C, Yoshida CK, Reichardt LF (1996) Neurotrophin-3 is a survival factor in vivo for early mouse trigeminal neurons. J Neurosci 16:7661-7669.

Wyatt S, Davies AM (1993) Regulation of expression of mRNAs encoding the nerve growth factor receptors p75 and trkA in developing sensory neurons. Development 119:635-648.

Wyatt S, Davies AM (1995) Regulation of nerve growth factor receptor gene expression in sympathetic neurons during development. J Cell Biol 1301435-1446:1435-1446.

Wyatt S, Piñón LGP, Ernfors P, Davies AM (1997) Sympathetic neuron survival and TrkA expression in NT3-deficient mouse embryos. EMBO J 16:3115-3123.

Yeo TT, Chua-Couzens J, Butcher LL, Bredesen DE, Cooper JD, Valletta JS, Mobley WC, Longo FM (1997) Absence of p75NTR causes increased basal forebrain cholinergic neuron size, choline acetyltransferase activity, and target innervation. J Neurosci 17:7594-7605.

Zhang D, Yao L, Bernd P (1994) Expression of trk and neurotrophin mRNA in dorsal root and sympathetic ganglia of the quail during development. J Neurobiol 25:1517-1532. 